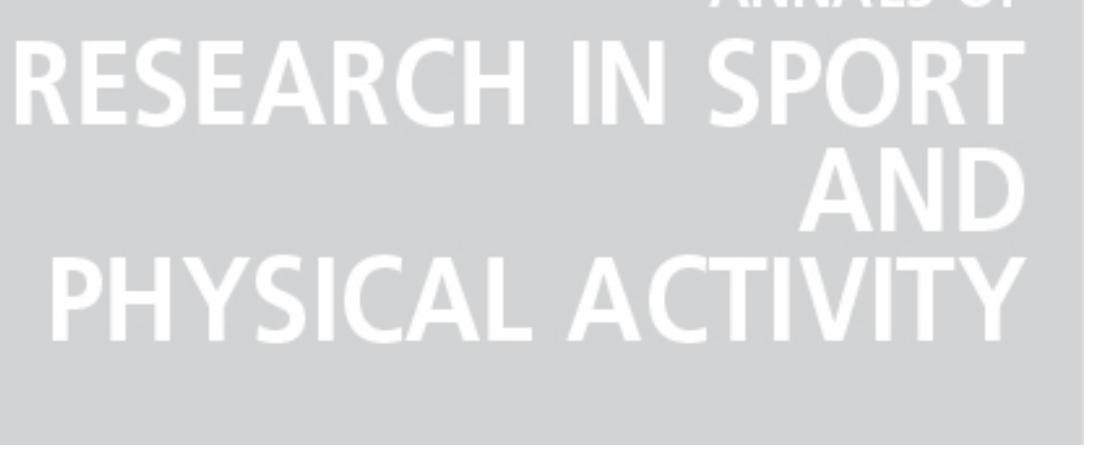

Growth, maturity profile and peak vo2 of 11 year-old male soccer players

Autor(es): $\quad$ Severino, Vítor; Gonçalves, Ricardo R.; Silva, Manuel J. Coelho e; Figueiredo, António J.

Publicado por: Imprensa da Universidade de Coimbra

URL persistente:

URI:http://hdl.handle.net/10316.2/3367

DOI:

DOI:http://dx.doi.org/10.14195/2182-7087_2_3

Accessed : $\quad$ 26-Apr-2023 14:30:57

A navegação consulta e descarregamento dos títulos inseridos nas Bibliotecas Digitais UC Digitalis, UC Pombalina e UC Impactum, pressupõem a aceitação plena e sem reservas dos Termos e Condições de Uso destas Bibliotecas Digitais, disponíveis em https://digitalis.uc.pt/pt-pt/termos.

Conforme exposto nos referidos Termos e Condições de Uso, o descarregamento de títulos de acesso restrito requer uma licença válida de autorização devendo o utilizador aceder ao(s) documento(s) a partir de um endereço de IP da instituição detentora da supramencionada licença.

Ao utilizador é apenas permitido o descarregamento para uso pessoal, pelo que o emprego do(s) título(s) descarregado(s) para outro fim, designadamente comercial, carece de autorização do respetivo autor ou editor da obra.

Na medida em que todas as obras da UC Digitalis se encontram protegidas pelo Código do Direito de Autor e Direitos Conexos e demais legislação aplicável, toda a cópia, parcial ou total, deste documento, nos casos em que é legalmente admitida, deverá conter ou fazer-se acompanhar por este aviso. 
(2) 2011

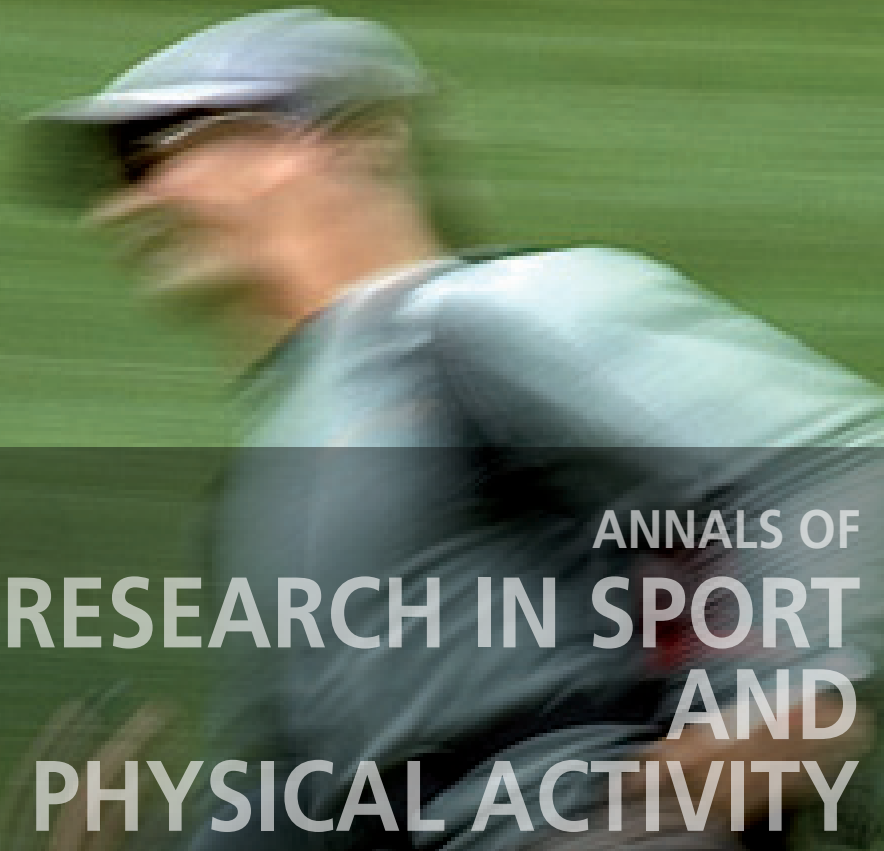

FACULDADE DE

CIÊNCIAS DO

DESPORTO E

EDUCAÇÃO FÍSICA DA UNIVERSIDADE DE COIMBRA

IMPRENSA

DA UNIVERISDADE

DE COIMBRA 


\section{2・SPORT TRAINING}

GROWTH, MATURITY PROFILE AND PEAK VO2 OF 11 YEAR-OLD MALE SOCCER PLAYERS 
Vítor Severino', Ricardo R. Gonçalves, Manuel J. Coelho e Silva, António J. Figueiredo Faculty of Sport Science and Physical Education - University of Coimbra. Portugal

\begin{abstract}
This study examined the relationship between body size, biological maturity, total amount of practice, and aerobic fitness of youth soccer players. The sample included 30 male soccer players aged 11 years old. Morphological variables (weight, height, sitting height and subcutaneous skinfolds), maturity (maturity offset, percentage of predicted mature height and skeletal maturity using the Fels method), quantity of annual practice and years of federate practice were considered. Assessment of aerobic power was obtained using a direct, maximal and progressive treadmill protocol. Data analysis considered general and comparative descriptive statistic. Pearson's correlation coefficient was calculated in order to consider the association between aerobic power outputs and morphology, maturity and sport participation parameters. ANOVA was used to compare variables by tactical playing position and among maturity status groups. Significance was maintained in $5 \%$. The maturity status-associated analysis classifies more subjects on time (53\%) followed by early mature (27\%) and late mature (20\%). Subjects classified as early matures showed higher average results for the morphological parameters (excluding sitting height/standing height ratio), amount of playing minutes and absolute aerobic power, while maturity delayed subjects showed higher relative aerobic power marks. Results illustrate defenders as taller, heavier, higher in adiposity, with superior amount of playing minutes and better in absolute aerobic power. We found strong correlations between absolute aerobic power and weight $(r=+0.90, p<0.01)$, height $(r=+0.76, p<0.01)$, maturity offset $(r=+0.80, p<0.01)$ and percentage of predicted adult height $(r=+0.77, p<0.01)$. Moderate correlation between absolute aerobic power and amount of playing minutes $(r=+0.34, p<0.05)$ was also found. Aerobic power seems to be associated with body size and maturity status. It seems that the process of sportive selection favours body size and maturity advanced athletes. Nevertheless, it seems that youth soccer coaches tend to select those players to defensive playing positions.
\end{abstract}

KEYWORDS: YouthSoccer. Biological maturity. Aerobic power.

\footnotetext{
${ }^{1}$ Vítor José Santos Severino Faculdade de Ciências do Desporto e Educação Física da Universidade de Coimbra, Estádio Universitário, Pavilhão III, 3040 - 156 Coimbra, Portugal. E-mail: vitorjss@gmail.com. Other e-mail contacts:Ricardo R. Gonçalves [r.rebelo.g@portugalmail.pt]Manuel J. Coelho e Silva [mjcesilva@fcdef.uc.pt] António J. Figueiredo [afigueiredo@fcdef.uc.pt]
} 


\section{INTRODUCTION}

Soccer is unarguably the most popular sport in the world (Reilly, Bangsbo\& Franks, 2000). In the particular case of Portugal, soccer occupies a social position of great prominence (Ramos, 2002). On the other hand, as stated by Morris (2000), early identification of future elite athletes will offer greater competitive potential to the sport organizations with that kind of capability. Paradoxically, the sports models used by most of professional clubs still seem to use too much support from empirical knowledge (Vaeyens et al., 2006).

Studies related to multidimensional research on youth soccer players (Malina et al., 2000; Seabra, Maia \&Garganta, 2001; Fragoso et al., 2004; Malina et al., 2005; Philippaerts et al., 2006; Vaeyens et al., 2006; Malina, Ribeiro, Aroso\& Cumming, 2007; Figueiredo, Gonçalves, Coelho e Silva \&Malina, 2009) have been increasing in the last decade, but still left open more discriminating analysis considering factors of metabolic response trough the use of laboratory tests.

Due to the length of the game, aerobic metabolism is the main source in soccer (Bangsbo, 1994; Impellizzeri, Mognoni, Sassi\&Rampinini, 2005; Stølen, Chamari, Castagna\&Wisløff, 2005; Svensson\&Drust, 2006). According to Reilly, Bangsbo\& Franks (2000), the energy expenditure associated with match play revolves around $5700 \mathrm{~kJ}$ for a male soccer player with total body mass of about $75 \mathrm{~kg}$. Maximal oxygen uptake has been studied in several studies with elite adult soccer players. Considering mean values, these are located between 56 and $69 \mathrm{ml} \cdot \mathrm{kg}^{-1} \cdot \mathrm{min}^{-1}$ (Reilly, Bangsbo\& Franks, 2000). Although Wisløff, Helgerud\& Hoff (1998) point out that the average values for elite player can be greater than $65 \mathrm{ml} . \mathrm{kg}^{-1} \cdot \mathrm{min}^{-1}$ (considering variability associated with tactical playing position), Reilly (2004) suggests that there is a threshold value of about $60 \mathrm{ml} \cdot \mathrm{kg}^{-1} \cdot \mathrm{min}^{-1}$, which represents the minimum for a soccer player succeed in a contemporary elite team. Although players of different tactical playing positions have a different workload during a game, which demonstrates that some of the training sessions should be dedicated to training specific to each position, few studies of young soccer players are available to date (Gil et al., 2007).

VO2max develops just like other process related to growth and maturation during childhood and adolescence (Helmantel, Elferink-Gemser\&Visscher, 2009), appearing to occur a stabilization of values expressed per unit body mass as a result of aging (Malina, Bouchard \& Bar-Or, 2004b). Furthermore, Beunen et al. (2002) found that although VO2max is largely explained by body mass, factors such as regular physical activity and his interaction with maturity status contribute independently to the VO2max. Maturity advanced boys attain higher absolute (L. $\mathrm{min}^{-1}$ ) VO2max compared with delayed maturity subjects. When regarding to relative results $\left(\mathrm{ml}^{\mathrm{kg}} \mathrm{kg}^{-1} \cdot \mathrm{min}^{-1}\right)$, late maturity boys achieve higher rate of oxygen absorption per unit body mass, except in early adolescence.

Boys, as they enter puberty, experience a significant increase of VO2max that reaches maximum gains during peak height velocity (PHV), continuing to increase up to 16 years of age despite the decline in growth rate, suggesting that puberty influences improvement 
in aerobic fitness by increasing body size, particularly of cardiac dimensions, lungs, muscles and circulatory system (Geithner et al., 2004; Malina, Bouchard \& Bar-Or, 2004b; Armstrong \&Welsman, 2005; Rowland, 2004).

Although VO2max is the most commonly used term for maximal achieved oxygen uptake, the term more appropriated and suitable for children and youth is peak oxygen uptake (Armstrong, 2006; Mamen, Resaland, Mo \& Anderson, 2009), which is a stout variable that is positively associated with the determination of VO2max in adults (Welsman, Bywater, Farr, Welford \& Armstrong, 2005). The purpose of this study is to examine the association between morphology, maturity assessed using more than a single methodology, amount of annual practice, and aerobic fitness of youth soccer players, considering as well tactical playing position and maturity associated patterns.

\section{METHODS}

The sample included 30 male soccer players aged $11.3-12.3$ years $(11.9 \pm 0.3)$ from three clubs in the midlands of Portugal. The athletes were grouped in four playing position categories: Goalkeepers $(n=2)$, Defenders $(n=9)$, Midfielders $(n=11)$ and Forwards $(n=8)$. All subjects were informed of the procedures involving data recording, giving authorization for data recording and divulgation, but not personal information.

Weight, height and sitting height were taken. The triceps, biceps, subscapular, suprailiac and medial calf skinfolds (Carter and Heat, 1990) were measured. The body mass index (BMI, $\mathrm{kg} / \mathrm{m}^{2}$ ) and sitting height/standing height ratio (\%) were also calculated.

Maturation was assessed through somatic indicators such as maturity offset (Mirwald, Baxter-Jones, Bailey, \&Beunen, 2002) and percentage of predicted adult height (\%PAH) (Khamis\& Roche, 1994 and 1995). Hand-wrist radiographs were also taken in order to provide an estimate of skeletal maturity. The Fels method was used to estimate a skeletal age for each child (Roche, Chumlea\&Thissen, 1988). A single experienced individual assessed all the radiographs.

Chronological age (CA) was subtracted from skeletal age (SA) for each child to provide an estimate of the skeletal maturity status (Peña Reyes, Cardenas-Barahona\&Malina, 1994; Malina et al., 2000; Peña Reyes \&Malina, 2004) for each subject as follows:

- Late $($ delayed $)=$ SA behind CA by more than one year;

- Average (on time) $=$ SA within plus or minus one year of CA;

- Early (advanced) $=$ SA ahead of CA by more than one year.

Assessment of aerobic power (peak VO2) was obtained using a direct, maximal and progressive treadmill protocol. Initially the children were habituated to both the general 
environment and the specific experimental procedures and then they warmed up by running on the treadmill at a speed of $5 \mathrm{~km} / \mathrm{h}$ for 3 minutes, ending at the initial speed of the protocol, $8 \mathrm{~km} / \mathrm{h}$. The test had its beginning at aspeed of $8 \mathrm{~km} / \mathrm{h}$ with an increment of 1 $\mathrm{km} / \mathrm{h}$ for every stage of 3 minutes. After setting the speed of $12 \mathrm{~km} / \mathrm{h}$ on the fifth stage the load increments were promoted trough slope, where in each stage increased $2.5 \%$.

The test was performed until voluntary exhaustion of the subject. After finishing the test, every subject performed an active recovery (5 minutes) on a bicycle ergometer Monarc 824E, without charge, at a constant speed of $60 \mathrm{rpm}$. If thechild showed signs of intense effort (hyperpnea, facial flushing, unsteady gait, sweating), supported by a heart rate leveled about $220 \mathrm{bpm}^{-1}$ minus age in years (range $\pm 5 \%$ ) and a respiratory exchange ratio at least 1.0, peak VO2 was accepted as a maximal index. Also, when an increase not exceeding $2 \mathrm{ml} . \mathrm{kg}^{-1}$. min $^{-1}$ despite an increase in load was verified, the attainment of VO2max was accepted as well (Armstrong, Welsman\&Winsley, 1996; Armstrong, Welsman\& Kirby, 1998; Armstrong \&Welsman, 2001; Geithner et al., 2004; Malina, Bouchard \& Bar-Or, 2004b).

Throughout the tests, inspired and expired gases were monitored continuously using an analysis system (MetamaxErgospirometry System; Cortex Biophysite GmbH 1991-1998) that was recalibrated prior to each test. Heart rate was monitored using a cardiofrequencimeter Polar S -810 .

The authors individually registered the number of training sessions, games and respective minutes over one season (2009 - 2010) on a weekly basis. Information about the number of seasons in federate sport was also gathered for each subject.

A sample of 10 players was measured on a second occasion within one week. Intraobserver technical errors of measurement and coefficients of reliability for anthropometric dimensions were calculated. The technical error of measurement is the square root of the squared differences of replicates divided by twice the number of pairs:

$$
\sigma_{e}=\sqrt{ } \sum d^{2} / 2 N(M a l i n a, \text { Hamill and Lemeshow, 1973). }
$$

It is also known as the measurement error standard deviation. The coefficient of reliability is based on the ratio of within-subject ( $r$ ) and inter-subject (s) variances:

$$
\mathrm{R}=1-\left(\mathrm{r}^{2} / \mathrm{s}^{2}\right) \text { (Mueller and Martorell, 1988). }
$$

Higher values indicate greater reliability. Technical errors and reliability coefficients for the present study are summarized in Table 1. Technical errors for anthropometric dimensions compare favorably with corresponding intra-observer errors in several health surveys in the United States and a variety of field surveys (Malina, 1995), while reliability coefficients indicate high reliabilities. 


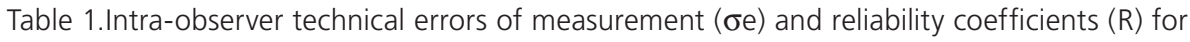
anthropometric dimensions $(n=10)$.

\begin{tabular}{l|c|c} 
& $\sigma_{\mathrm{e}}$ & $\mathrm{R}$ \\
\hline Weight, $\mathrm{kg}$ & 0.25 & 1.00 \\
\hline Height, cm & 0.75 & 0.99 \\
\hline Sitting height, cm & 0.72 & 0.97 \\
\hline Skinfolds, mm & & \\
\hline Triceps & 0.50 & 0.98 \\
\hline Biceps & 0.47 & 0.97 \\
\hline Subscapular & 0.32 & 0.98 \\
\hline Suprailiac & 0.52 & 0.97 \\
\hline Medial calf & 0.42 & 0.99 \\
\hline
\end{tabular}

Data analysis considered general and comparative (maturity status and playing position) descriptive statistic. Pearson's correlation coefficient was calculated in order to analyse the association between aerobic power outputs and morphology, maturity and sport participation parameters. One-way analysis of variance (ANOVA) was used to compare CA, maturity variables, body size and proportions, annual amount of practice and aerobic power by tactical playing position and among late, average (on time) and early maturing players within competitive age group. Significance was maintained in 5\%.

\section{RESULTS}

Descriptive statistics for variables of biological maturity and years of federate practice are summarized in table 2 . There is a greater range of variance of skeletal age (5.9 years) compared to chronological age (1.0 years), within this age group of soccer players. It was estimated that, on average, peak height velocity (PHV) will occur at about 13.8 years of age and also, moreover, the subjects of our sample are currently approximately 2.2 years from achieving this biological event. 
Table 2.Descriptive statistics (mean $\pm \mathrm{sd}$ ) and range values (maximum - minimum) for biological maturity and years of federate practice $(n=30)$.

\begin{tabular}{l|c|c|c|c} 
& Minimum & Maximum & Range & Mean \pm SD \\
\hline Chronological Age, yrs & 11.3 & 12.3 & 1.0 & $11.9 \pm 0.3$ \\
\hline Skeletal Age, yrs & 8.7 & 14.6 & 5.9 & $12.0 \pm 1.5$ \\
\hline Maturity Offset, yrs & -3.10 & -0.60 & 2.5 & $-2.20 \pm 0.60$ \\
\hline Age PHV, yrs & 12.7 & 14.6 & 1.9 & $13.8 \pm 0.4$ \\
\hline PAH, \% & 78.8 & 90.7 & 11.9 & $83.6 \pm 2.6$ \\
\hline FederatePractice, yrs & 1 & 6 & 5 & $3.8 \pm 1.5$ \\
\hline
\end{tabular}

Table 3 summarizes descriptive statistics for morphology, total amount of annual practice and aerobic power. The absolute and relative mean values for peak VO2were estimated in $2.33 \mathrm{~L}$. $\mathrm{min}^{-1}$ and $60.9 \mathrm{ml} . \mathrm{kg}^{-1} \cdot \mathrm{min}^{-1}$ respectively. There is a significant range of variation within this age group of soccer players for body mass and height, $53.7 \mathrm{~kg}$ and $35.0 \mathrm{~cm}$ respectively. The average annual volume for each player, concerning sport participation, (training sessions and games) was estimated in 7179.4 minutes.

Table 3.Descriptive statistics (mean $\pm \mathrm{sd}$ ) and range values (maximum - minimum) for morphology variables, amount of annual practice and aerobic power $(n=30)$.

\begin{tabular}{l|c|c|c|c} 
& Minimum & Maximum & Range & Mean \pm SD \\
\hline Weight, kg & 29.4 & 83.1 & 53.7 & $38.8 \pm 10.0$ \\
Height, cm & 132.5 & 167.5 & 35.0 & $146.0 \pm 8.1$ \\
BMI, kg/m² & 15.3 & 33.4 & 18.1 & $18.1 \pm 3.2$ \\
SitHt/Ht Ratio, \% & 48.7 & 54.2 & 5.5 & $51.7 \pm 1.3$ \\
Sum ofskinfolds, mm & 19 & 78 & 59 & $32.0 \pm 12.3$ \\
\hline Training sessions, \# & 47 & 102 & 55 & $81.4 \pm 16.1$ \\
Game sessions, \# & 4 & 24 & 20 & $15.5 \pm 5.2$ \\
Annualsessions, \# & 54 & 126 & 72 & $96.9 \pm 20.1$ \\
Training minutes, min & 2820 & 9060 & 6240 & $6596.0 \pm 2044.0$ \\
Game minutes, min & 113 & 1350 & 1237 & $583.4 \pm 239.6$ \\
Annual minutes, min & 3210 & 10410 & 7200 & $7179.4 \pm 2146.1$ \\
\hline Treadmill - stage & 3 & 8 & 5 & $5.8 \pm 1.1$ \\
Treadmill - final HR, bpm & 179 & 212 & 33 & $197.2 \pm 8.8$ \\
Treadmill - RER & 0.90 & 1.02 & 0.12 & $0.96 \pm 0.03$ \\
Peak VO2, L.min-1 & 1.66 & 3.88 & 2.22 & $2.33 \pm 0.43$ \\
Peak VO2, ml.kg ${ }^{-1}$.min ${ }^{-1}$ & 46.7 & 70.1 & 23.4 & $60.9 \pm 5.9$ \\
\hline
\end{tabular}


The average values and standard deviations for biological maturation and years of federate practice, grouping the subjects according to their tactical playing position, are considered in table 4. Defenders showed higher mean results for skeletal age and percentage of predicted adult height (\%PAH), as well as they are significantly older (CA) and have more years in the competitive formal process $(F=4.74, p<0.01)$. Data further demonstrates that defenders are, significantly, closer to peak height velocity (PHV) and therefore they are expected to reach that point at earlier ages, comparing to the remaining groups.

Table 4 Descriptive statistics (mean $\pm \mathrm{sd}$ ) and results of ANOVAs for biological maturity and years of federate practice, considering tactical playing position $(n=28)$.

\begin{tabular}{lc|c|c|c|c} 
& \multicolumn{3}{c}{ Tactical Playing Position } & \multicolumn{2}{c}{} \\
\cline { 2 - 5 } & $\begin{array}{c}\text { Defenders } \\
(\mathrm{n}=9)\end{array}$ & $\begin{array}{c}\text { Midfielders } \\
(\mathrm{n}=11)\end{array}$ & $\begin{array}{c}\text { Forwards } \\
(\mathrm{n}=8)\end{array}$ & $\mathrm{F}$ & $\mathrm{p}$ \\
\hline Variable & Mean $\pm \mathrm{SD}$ & Mean $\pm \mathrm{SD}$ & Mean $\pm \mathrm{SD}$ & \\
\hline Chronological Age, yrs & $12.1 \pm 0.2$ & $11.7 \pm 0.2$ & $11.9 \pm 0.3$ & 6.19 & $<0.01$ \\
Skeletal Age, yrs & $12.8 \pm 1.8$ & $12.1 \pm 1.0$ & $11.6 \pm 1.2$ & 2.80 & - \\
Maturity Offset, yrs & $-1.73 \pm$ & $-2.38 \pm$ & $-2.39 \pm$ & 3.22 & $<0.05$ \\
Age PHV, yrs & 0.72 & 0.45 & 0.44 & 1.75 & - \\
PAH, \% & $13.6 \pm 0.6$ & $13.8 \pm 0.3$ & $14.1 \pm 0.3$ & 1.75 & - \\
\hline Federate Practice, yrs & $85.0 \pm 3.7$ & $83.0 \pm 1.8$ & $83.1 \pm 1.9$ & 1.43 & - \\
\hline
\end{tabular}

* Goalkeepers $(n=2)$ were not considered

Table 5 considers descriptive statistics for morphology, total amount of annual practice and aerobic power, according to maturity status groups - given by the difference between skeletal and chronological age. When regarding to the indicators of external morphology, we verified a growing trend for weight and height considering delayed, average and early mature groups. This trend was also established for peak VO2 $\left(\mathrm{L}_{\mathrm{min}} \mathrm{mi}^{-1}\right)$. On the other hand, when peak VO2 was considered in relation to body mass $\left(\mathrm{ml}^{\mathrm{kg}} \mathrm{kg}^{-1} \cdot \mathrm{min}^{-1}\right)$ the results were significantly $(F=4.42, p<0.05)$ higher in the late maturity group. It is also observable that the advanced maturity soccer players attained higher mean results for game sessions (16.8 annual game sessions) and game minutes (622.1 annual game minutes). 
Table 5 Descriptive statistics (mean $\pm \mathrm{sd}$ ) and results of ANOVAs for morphology variables, amount of annual practice and aerobic power, considering maturity status $(n=30)$.

\begin{tabular}{|c|c|c|c|c|c|}
\hline & \multicolumn{3}{|c|}{ Maturity Status } & \multirow[b]{2}{*}{$\mathrm{F}$} & \multirow[b]{2}{*}{$p$} \\
\hline & $\begin{array}{l}\text { Late } \\
(n=6)\end{array}$ & $\begin{array}{c}\text { Average } \\
(n=16)\end{array}$ & $\begin{array}{l}\text { Early } \\
(n=8)\end{array}$ & & \\
\hline Variable & Mean \pm SD & Mean \pm SD & Mean \pm SD & & \\
\hline Weight, kg & $33.1 \pm 3.3$ & $39.8 \pm 12.3$ & $41.3 \pm 6.9$ & 1.34 & - \\
\hline Height, cm & $140.7 \pm 5.4$ & $145.6 \pm 6.8$ & $150.9 \pm 10.1$ & 3.17 & - \\
\hline $\mathrm{BMI}, \mathrm{kg} / \mathrm{m}^{2}$ & $16.7 \pm 0.7$ & $18.6 \pm 4.2$ & $18.0 \pm 1.4$ & 0.75 & - \\
\hline SitHt/Ht Ratio, \% & $51.5 \pm 1.0$ & $52.2 \pm 1.0$ & $50.9 \pm 1.6$ & 2.99 & - \\
\hline Sum ofskinfolds, mm & $23.2 \pm 3.4$ & $35.5 \pm 15.3$ & $31.6 \pm 4.7$ & 2.41 & - \\
\hline Training sessions, \# & $87.0 \pm 19.7$ & $79.1 \pm 15.5$ & $81.8 \pm 15.8$ & 0.51 & - \\
\hline Game sessions, \# & $15.2 \pm 8.9$ & $15.0 \pm 4.3$ & $16.8 \pm 3.4$ & 0.31 & - \\
\hline Annualsessions, \# & $102.2 \pm 27.5$ & $94.1 \pm 18.6$ & $98.5 \pm 18.7$ & 0.37 & - \\
\hline Training minutes, min & $7495.0 \pm 2305.3$ & $6135.0 \pm 1910.4$ & $6843.8 \pm 2107.9$ & 1.05 & - \\
\hline Game minutes, min & $585.2 \pm 441.0$ & $563.3 \pm 197.5$ & $622.1 \pm 112.8$ & 0.15 & - \\
\hline Annual minutes, min & $8080.2 \pm 2590.8$ & $6698.3 \pm 1962.4$ & $7465.9 \pm 2171.8$ & 1.00 & - \\
\hline Treadmill - stage & $6.3 \pm 1.0$ & $5.7 \pm 1.3$ & $5.6 \pm 0.9$ & 0.84 & - \\
\hline Treadmill - HR, bpm & $201.7 \pm 7.6$ & $194.8 \pm 9.1$ & $198.8 \pm 8.4$ & 1.53 & - \\
\hline Treadmill - RER & $0.97 \pm 0.04$ & $0.96 \pm 0.04$ & $0.97 \pm 0.03$ & 0.46 & - \\
\hline Peak VO2, L. min $^{-1}$ & $2.18 \pm 0.22$ & $2.29 \pm 0.49$ & $2.55 \pm 0.38$ & 1.55 & - \\
\hline Peak VO2, $\mathrm{ml} \cdot \mathrm{kg}^{-1} \cdot \mathrm{min}^{-1}$ & $65.9 \pm 2.4$ & $58.5 \pm 6.4$ & $62.1 \pm 4.2$ & 4.42 & $<0.05$ \\
\hline
\end{tabular}

Descriptive statistics for morphology, total amount of annual practice and aerobic 44 - power, considering tactical playing position groups are summarized in table 6. Defenders are significantly heavier $(F=2.87, p<0.05)$ and showed higher mean results for height, as well as for sumof skinfolds and body mass index. In addition to body size, defenders also attained significantly better results for absolute peak VO2 ( $F=3.01, p<0.05)$. In the meantime, when the variable is considered in relation to body mass, the mean results are higher in forwards (62.2 ml. $\left.\mathrm{kg}^{-1} \cdot \mathrm{min}^{-1}\right)$ followed by midfielders $\left(62.0 \mathrm{ml}^{\mathrm{kg}} \mathrm{kg}^{-1} \cdot \mathrm{min}^{-1}\right)$ and defenders $\left(59.1 \mathrm{ml} . \mathrm{kg}^{-1}\right.$. $\left.\mathrm{min}^{-1}\right)$. Further more, defenders have accumulated significantly more game minutes during the previous season $(F=3.84, p<0.05)$. 
Table 6 Descriptive statistics (mean $\pm \mathrm{sd}$ ) and results of ANOVAsfor morphology variables, amount of annual practice and aerobic power, considering tactical playing position $(n=28)$.

\begin{tabular}{|c|c|c|c|c|c|}
\hline \multirow{3}{*}{ Variable } & \multicolumn{3}{|c|}{ Tactical Playing Position } & \multirow{3}{*}{$\mathrm{F}$} & \multirow{3}{*}{$p$} \\
\hline & $\begin{array}{l}\text { Defenders } \\
\qquad(n=9)\end{array}$ & $\begin{array}{l}\text { Midfielders } \\
\qquad(n=11)\end{array}$ & $\begin{array}{l}\text { Forwards } \\
\qquad(n=8)\end{array}$ & & \\
\hline & Mean \pm SD & Mean \pm SD & Mean \pm SD & & \\
\hline Weight, kg & $46.3 \pm 15.6$ & $35.7 \pm 4.2$ & $35.1 \pm 2.9$ & 2.87 & $<0.05$ \\
\hline Height, cm & $151.5 \pm 10.4$ & $144.2 \pm 6.1$ & $142.6 \pm 6.2$ & 2.33 & - \\
\hline $\mathrm{BMI}, \mathrm{kg} / \mathrm{m}^{2}$ & $19.9 \pm 5.1$ & $17.2 \pm 1.8$ & $17.3 \pm 1.4$ & 1.44 & - \\
\hline SitHt/Ht Ratio, \% & $51.4 \pm 1.3$ & $52.1 \pm 1.6$ & $51.8 \pm 0.8$ & 0.64 & - \\
\hline Sum ofskinfolds, mm & $37.2 \pm 16.0$ & $29.9 \pm 11.3$ & $28.1 \pm 7.2$ & 0.96 & - \\
\hline Training sessions, \# & $87.9 \pm 10.2$ & $75.6 \pm 16.4$ & $77.8 \pm 19.2$ & 1.97 & - \\
\hline Game sessions, \# & $17.8 \pm 3.1$ & $15.4 \pm 3.7$ & $12.9 \pm 7.0$ & 1.34 & - \\
\hline Annualsessions, \# & $105.7 \pm 12.9$ & $91.0 \pm 19.7$ & $90.6 \pm 24.6$ & 1.79 & - \\
\hline Training minutes, min & $7053.3 \pm 1772.5$ & $6283.6 \pm 2047.2$ & $6322.5 \pm 2495.0$ & 0.35 & - \\
\hline Game minutes, min & $712.8 \pm 158.5$ & $535.9 \pm 140.3$ & $433.4 \pm 200.1$ & 3.84 & $<0.05$ \\
\hline Annual minutes, min & $7766.1 \pm 1768.2$ & $6819.6 \pm 2100.7$ & $6755.9 \pm 2582.2$ & 0.56 & - \\
\hline Treadmill - stage & $5.2 \pm 1.2$ & $6.2 \pm 1.1$ & $6.0 \pm 1.1$ & 1.40 & - \\
\hline Treadmill - HR, bpm & $195.6 \pm 6.2$ & $198.7 \pm 9.9$ & $198.9 \pm 9.0$ & 0.73 & - \\
\hline Treadmill - RER & $0.96 \pm 0.04$ & $0.98 \pm 0.04$ & $0.95 \pm 0.02$ & 1.16 & - \\
\hline Peak VO2, L. $\mathrm{min}^{-1}$ & $2.66 \pm 0.60$ & $2.21 \pm 0.28$ & $2.18 \pm 0.19$ & 3.01 & $<0.05$ \\
\hline Peak VO2, $\mathrm{ml} \cdot \mathrm{kg}^{-1} \cdot \mathrm{min}^{-1}$ & $59.1 \pm 7.5$ & $62.0 \pm 5.4$ & $62.2 \pm 3.9$ & 0.66 & - \\
\hline
\end{tabular}

* Goalkeepers $(n=2)$ were not considered

Correlations between peak VO2 and morphology, biological maturity, and sport participation parameters are summarized in table 7 . Results suggests, for absolute peak VO2, strong correlations with weight, height, body mass index, maturity offset, age at peak height velocity and percentage of predicted adult height. Moderate correlations were also found for sum of skinfolds, chronological age, skeletal age and annual game minutes. Regarding to relative peak VO2, we found a strong, negative correlation with sum of skinfolds and also negative, moderate correlations with weight and body mass index. A positive, moderate correlation with age in peak height velocity was found as well. The results suggest that maturity advanced soccer players, with larger body size, achieved better absolute peak VO2 results and, furthermore, youth soccer players with higher absolute peak VO2were more often selected by coaches during the previous season. 
Table 7 - Correlations between peak VO2 outputs and morphology, biological maturity, years of federate practice and amount of annual practice $(n=30)$.

\begin{tabular}{|c|c|c|}
\hline & Peak VO2, L.min ${ }^{-1}$ & Peak VO2, ml. $\mathrm{kg}^{-1} \cdot \mathrm{min}^{-1}$ \\
\hline Weight, kg & $+0.90 * *$ & $-0.56^{* *}$ \\
\hline Height, cm & $+0.76^{* *}$ & -0.20 \\
\hline $\mathrm{BMI}, \mathrm{kg} / \mathrm{m}^{2}$ & $+0.72 * *$ & $-0.63^{* *}$ \\
\hline SitHt/Ht Ratio, \% & -0.18 & -0.05 \\
\hline Sum ofskinfolds, mm & $+0.51 * *$ & $-0.77^{* *}$ \\
\hline Chronological Age, yrs & $+0.46^{*}$ & +0.09 \\
\hline Skeletal Age, yrs & $+0.42 *$ & -0.19 \\
\hline Maturity Offset, yrs & $+0.80 * *$ & -0.32 \\
\hline Age PHV, yrs & $-0.71 * *$ & $+0.39 *$ \\
\hline $\mathrm{PAH}, \%$ & $+0.77 * *$ & -0.24 \\
\hline Federate Practice, yrs & +0.21 & +0.09 \\
\hline Training sessions, \# & +0.13 & -0.05 \\
\hline Game sessions, \# & +0.23 & +0.11 \\
\hline Annualsessions, \# & +0.16 & -0.02 \\
\hline Training minutes, min & +0.04 & +0.09 \\
\hline Game minutes, min & $+0.34^{*}$ & +0.03 \\
\hline Annual minutes, min & +0.08 & +0.09 \\
\hline
\end{tabular}

n.s. (not-significant). ${ }^{*}(p<.05) .{ }^{* *}(p<.01)$.

\section{DISCUSSION}

Assuming data from the Centers for DiseaseControl and Prevention - United States of America(2001) as a reference, mean heights from our sample are between the $25^{\text {th }}$ and $50^{\text {th }}$ percentiles. If we split the sample into tactical playing position groups, this same trend is only observed for midfielders, while forwards are located close to the $25^{\text {th }}$ percentile. Defenders, on the other hand, are between the $50^{\text {th }}$ and $70^{\text {th }}$ percentiles. Considering mean weights, similar trends were found. However, results approximate the $75^{\text {th }}$ percentile in the defenders group, taking into account tactical playing position. Physical contact, concerning soccer, is crucial in areas closer to the goals. Thus, youth soccer coaches seem to select heavier and taller players to those field areas - defenders and forwards (Figueiredo, 2007). The results from our investigation seem to fit into this conjecture, but only when regarding to defenders. 
Age at peak height velocity was estimated using the maturity offset (Mirwald, BaxterJones, Bailey, \&Beunen, 2002). Malina et al. (2006) described this method as noninvasive and efficient, whilst acknowledging some reservations to its applications. According to Mirwald, Baxter-Jones, Bailey, \&Beunen (2002) the age of occurrence of this biological event can be determined in $95 \%$ of cases, with an accuracy of 1.0 years. Thus, it seems that this methodology enables to gather the subjects, with some certainty, in equivalent maturity groups (Figueiredo, 2007).

Apart from the conceptual sphere of scientific research, we believe that the ability to fit young soccer players in the growth curve rate can be quite useful as we can place the period in which the subject is growing faster, consequently more vulnerable to inadequate training plans or, therefore, more in need of a specific, individualized, training intervention. Our results suggest that peak height velocity will occur, on average, at 13.8 years of age. Similar results were already found for European population (Malina, Bouchard \& Bar-Or, 2004b) and for youth soccer players (Philippaerts et al., 2006).

The distribution of soccer players in the categories resulting from the discrepancy between skeletal age and chronological age evidence that the group classified as average or "on time" has a higher presence $(53.3 \%)$, followed by early matures $(26.7 \%)$ and late matures (20.0\%). These results are in line with the evidence reported by Malina (2004a), in which young athletes (boys) tend, with some exceptions, to be "on time" or early matures. In the meantime, Le Gall, Carling \& Reilly (2007) found, with a considerably larger sample of soccer players ( $n=233$ ) but with an older age group (Under 14), a substantial lower percentage of late matures. This evidence seems to meet the trends reported by Malina et al. (2000), Peña Reyes \&Malina (2004) and Figueiredo, Gonçalves, Coelho e Silva \&Malina (2009), regarding that with sport experience and aging maturity advanced athletes seem to appear more frequently within their respective specific sports. We have, however, to establish a limitation when approaching to Le Gall, Carling \& Reilly (op cit.) study, since the skeletal age method used (Greulich-Pyle) was different from the one we used in the present study (Fels).

Young athletes tend to have higher levels of aerobic power per unit body mass than the general population children and youth non-athletes (Malina, Bouchard \& Bar-Or, 2004). This trend finds echo in previous researches (Eisenman, Pivarnik\&Malina, 2001; Chamari et al., 2004; Montfort-Steiger, Williams \& Armstrong, 2005; Metaxas, Koutlianos, Kouidi\&Deliggianis, 2005; Castagna, Impellizzeri, Rampinini, D’Ottavio\&Manzi, 2008). Our results strengthen the framework of evidence and show youth soccer players as athletes who demonstrate values of relative peak VO2 similar to those find for their peers from other sports. Yet, it must be considered that among the referenced studies only the investigation of Eisenman, Pivarnik\&Malina (op cit.) corresponds to the age group of our sample. The other sample sets are between 15.7 and 18.1 years of age. In the meantime, and considering only age groups similar to our sample of soccer players, our results were higher than those found in groups of healthy children reported in the studies of Armstrong, Kirby \& McManus (1995), Rowland, Goff, Martel \&Ferrone (2000), Vinet et al. (2003) and Gursel, Sonel, Gok\&Yalçin 
(2004). This trend is also verifiable if the results are compared with healthy trained children (Nourry et al., 2004). When the values are considered in absolute terms, the evidence remains, considering all the studies already referenced.

Our study does not fit the perspective characterized by Stølen, Chamari, Castagna\&Wisløff (2005), which stated that youth soccer players tend to show lower values of relative VO2max $\left(<60 \mathrm{ml} \cdot \mathrm{kg}^{-1} \cdot \mathrm{min}^{-1}\right)$ compared to adult athletes. However, there is still a gap to be filled when it comes to analyzing studies with young soccer players in pubescent ages.

There is a strong association between maximum oxygen consumption and body size (Malina, Bouchard \& Bar-Or, 2004b). The same authors reported that there appeared to be a stabilization of the values expressed per unit body mass, as a result of aging, suggesting a proportional increase between the maximum oxygen consumption and body size. These evidences seem to be observable in our study, as it is clear a very high degree of association between absolute aerobic power and body mass. We found, as well, high correlations with height and body mass index. When the values of aerobic power are considered in relation to body mass, the most obvious sign is that all associations are to be inversely proportional and of lesser magnitude of correlation, except the sum of skinfolds, which still presents a strong, negative correlation.

Our study seems to point towards that young soccer players who are advanced in maturity, achieve better results in the test of aerobic power. However, when peak VO2 considers body mass, late mature athletes seem to get better results. These findings are in line with Malina\& Bouchard (1991) and Armstrong \&Welsman (2001). This trend is further strengthened by the values of aerobic power in young soccer players according to maturity status given by the discrepancy between skeletal age and chronological age. In the present investigation the highest values of absolute aerobic power were estimated for the advanced maturity status group. On the other hand, when the figures take into account the body weight, it appears that is the group of delayed maturity status that presents the higher results.

The present investigation seem to confirm the trends that, on the one hand, improvements in aerobic fitness are associated with maturation and increased body size (Armstrong \&Welsman, 2005; Geithner et al., 2004; Malina, Bouchard \& Bar-Or, 2004b) and, secondly, young athletes who are maturity advanced are privileged in relation to their peers "on time" and delayed (Peña Reyes \&Malina, 2004; Figueiredo, Gonçalves, Coelho e Silva \&Malina, 2009).

The sample from the present investigation corresponds to the same specific age group (11-year-olds), which restraint in the comprehension and inference about the sport training process. Upcoming studies should extend the sample and the number of subjects for each tactical playing position, as well as to monitor the data quality control for skeletal age and aerobic power variables. Since the interpretation of aerobic power in young people is confounded by the need of suitably partition out body size variation, the use of scaling techniques is needed. 


\section{CONCLUSIONS}

Our study supports the reported evidences which state that aerobic power increase in direct proportion to body mass. It is also supported that maturity advanced boys attain higher absolute peak VO2 $\left({\mathrm{L} . \mathrm{min}^{-1}}^{-1}\right)$ but, on the other hand, maturity delayed boys reach higher peak VO2 results per unit body mass $\left(\mathrm{ml}^{\mathrm{kg}}{ }^{-1} \cdot \mathrm{min}^{-1}\right)$. Regarding to tactical playing position, the defenders from our sample showed higher results for morphology, biological maturation and absolute peak VO2. They also attained higher values concerning to annual average game minutes. In other words, they were chose more often by coaches in their respective competitive process.

The evidence from our study seems to point that coaches tend to select young maturity advanced athletes to areas of the field nearest to the goal posts (where physical contact seems to be crucial). It seems to subsist, moreover, a hypothetical exacerbated concern about the defensive process, since the young players classified as forwards, besides less selected by coaches compared to defenders and midfielders, were also smaller, thinner and delayed in the maturity process.

Each tactical playing position seems to be related to a different functional and morphological profile that may, however, be related to the sport selection process, when using the maturity status of the young soccer player as the main criterion. Furthermore, youth soccer coaches must be aware that, besides playing position patterns and even in the same particular age group, there are significant differences regarding to morphology and aerobic fitness of youth soccer players in the same age group, so the training process itself must be carefully defined and adapted. Subsequently, more studies are needed.

\section{ACKNOWLEDGMENTS}

We thankfully appreciate the patience and cooperation of the young soccer players, coaches, parents and club managers.

\section{REFERENCES}

Armstrong, N., Kirby, B., \&McManus, A.M. (1995). Aerobic fitness of prepubescentchildren. Annals of Human Biology. 22(5): 427 - 441 .

Armstrong, N., Welsman, J.R., \&Winsley, R.J. (1996). Is Peak VO2 a Maximal Index of Children's Aerobic Fitness?. International Journal of Sports Medicine. Vol. 17: 356-359.

Armstrong, N., Welsman, J.R., \& Kirby, B.J. (1998). Peak Oxygen Uptake and Maturation in 12-yr Olds. Medicine \& Science in Sports \& Exercise. Vol. 30 (1): 165-169. 
Armstrong, N., \&Welsman, J.R. (2001). Peak Oxygen Uptake in Relation to Growth and Maturation in 11- to 17-year-old Humans. European Journal of Applied Physiology. Vol. 85: 546-551.

Armstrong, N., \&Welsman, J.R. (2005). Essay: Physiology of the Child Athlete. Lancet. Vol. 336 (1) (Suppl): S44-45.

Armstrong, N. (2006). Aerobic fitness of children and adolescent. Jornal de Pediatria, 82 (6): 406-408.

Bangsbo, J (1994). Fitness Training in Football - A Scientific Approach. Bagsvaerd: HO \& Storm.

Bangsbo, J., Mohr, M., \&Krustrup, P. (2006). Physical and metabolic demands of training and match play in the elite football player. Journal of Sport Sciences 24 (7): 665 - 674

Beunen, G., Baxter-Jones, A., Mirwald, R., Thomis, M., Lefevre, J., Malina, R.M., \& Bailey, D. (2002). Intraindividualallometric development of aerobic power in 8-to 16-year-old boys. Medicine \& Science in Sports \& Exercise, 33(3), 503-510.

Carter, J.E.L., \& Heath B.H., (1990). Somatotyping: Development and Applications. Cambridge University Press.

Castagna, C., Impellizzeri, F.M., Rampinini, E., D'Ottavio, S., \&Manzi, V. (2008). The Yo-Yo intermittent recovery test in basketball players. Journal of Science and Medicine in Sport. Vol. 11: 202-208.

Centers for Disease Control and Prevention (2000). National Center for Health Statistics. CDC growth charts: United States. http://www.cdc.gov/growthcharts.htm.

Chamari, K., Moussa - Chamari, I., \&Boussaidi, L. (2005). Appropriate interpretation of aerobic capacity: allometric scaling in adult and young soccer players. British Journal of Sports Medicine. Vol. 39 (2): 97-101.

Eisenman, J.C., Pivarnik, J.M., \&Malina, R.M. (2001). Scaling peak VO2 to body mass in young male and female distance runners. Journal of Applied Physiology. 90: 2172 - 2180.

Figueiredo, A. J. (2007). Growth, Maturation and Training - A study of youth soccer players 11-15 years of age. (Englishversion for defencepurpose). Faculdade de Ciências do Desporto e Educação Física. Universidade de Coimbra. July, 2007.

Figueiredo, A. J., Carlos E. Gonçalves, Manuel J. Coelho e Silva, \& Malina, R.M. (2009). Youth soccer players, 11-14 years: Maturity, size, function, skill and goal orientation. AnnalsofHumanBiology, 36(1): 60-73.

Fragoso, .I, Vieira, F., Canto e Castro, L., Oliveira Júnior, A., Capela, C., Oliveira, N., \& Barroso, A. (2004). Maturation and strength of adolescent soccer players. In M. Coelho e Silva, \& R.M. Malina (Eds). Children and Youth inOrganized Sports. Coimbra. Imprensa da Universidade.

Geithner, C.A., Thomis, M.A., Eynde, B.V., Mães, H.H.M., Loos, R.J.F., Peeters, M., Claessens, A., Vlietinck, R., Malina, R.M., \&Beunen, G.P. (2004). Growth in Peak Aerobic Power during Adolescence. Medicine \& Science in Sports \& Exercise. Vol. 36 (9): 1616-1624.

Gil, S. M., Gil, J., Ruiz, F., Irazusta, A., \&lrazusta, J. (2007). Physiological and Anthropometric characteristics of young soccer players according to their playing position: relevance for the selection process. Journal of Strength and Conditioning Research. 2007, 21(2), 438-445.

Gursel, Y., Sonel, B., Gok, H., Yalçin, P. (2004). The peak oxygen uptake of healthy Turkish children with reference to age and sex: a pilot study. The Turkish Journal of Pediatrics. 46: 38 - 43.

Helmantel, A., Elferink-Gemser, M., Visscher, C. (2009). Trainability of VO2max during childhood and adolescence. In Coelho e Silva M, Figueiredo A, Elferink-Gemser M \& Malina R (Eds.). Youth Sports: Participation, Trainability and Readiness. Imprensa da Universidade de Coimbra.

Impellizzeri, E., Mognoni, P., Sassi, A., \&Rampinini, E. (2005). Validity of a submaximal running test to evaluate aerobic fitness changes in soccer players. In Reilly, T., Cabri, J. \&Araújo, D. (Eds). Science and Football $\checkmark$ - The Proceedings of the Fifth World Congress on Science and Football. 105 - 111. 
Khamis, H. J., \& Roche, A. F. (1994). Predicting adult stature without using skeletal age: the Khamis - Roche method. Pediatrics, 94 (4), 504-507.

Khamis, H. J., \& Roche, A. F. (1995). Predicting adult stature without using skeletal age: the Khamis-Roche method. Pediatrics - erratum, 95(3), 457.

Le Gall, F., Carling, C., \& Reilly, T. (2007). Biological maturity and injury in elite youth football. Scandinavian Journal of Medicine and Science in Sports. 17: 564 - 572.

Malina, R.M., \& Bouchard, C. (1991). Growth, Maturation and Physical Activity. Champaign, Illinois.: Human Kinetics Publishers.

Malina, R.M. (1995). Anthropometry. In Physiological Assessment of Human Fitness, edited by P.J. Maud and C. Foster (Champaign, IL: Human Kinetics), pp. 205-219.

Malina, R.M., PeñaReyes, M.E., Eisenmann, J.C., Horta, L., Rodrigues, J., \& Miller, R. (2000). Height, mass and skeletal maturity of elite Portuguese soccer players aged $11 \pm 16$ years. Journal of Sports Sciences, 2000, 18, 685-693.

Malina, R. M., (2004a). Growth and Maturation: basic principles and effects of training. In M Coelho e Silva, RM Malina (Eds). Children and Youth in Organized Sports. Imprensa da Universidade de Coimbra / Coimbra UniversityPress.

Malina, R.M., Bouchard, C., \& Bar-Or, O. (2004b). Growth, maturation and physical activity, $2^{\text {nd }}$ Edition. Champaign, IL: Human Kinetics.

Malina, R.M., Cumming, S. P., Kontos, A.P., Eisenmann, J.C., Ribeiro, B., \&Aroso, J. (2005). Maturity-asociated variation in sport-specific skills of youth soccer players aged 13-15 years. Journal of Sports Sciences, May 2005; 23(5): 515-522.

Malina, R.M., Claessens, A.L., Van Aken, K., Thomis, M., Lefevre, J., Philipparts, R., \&Beunen, G. (2006). Maturity offset in gymnasts: application of a prediction equation. Medicine and Science in Sports and Exercise, Vol. 38 (7): 1342-1347.

Malina, R.M., Hamill, P.V.V., and Lemeshow, S. (1973). Selected measurements of children 6-11 years, United States. Vital and Health Statistics, Series 11, No. 123 (Washington, DC: Department of Health and Human Services, U.S. Government Printing Office).

Malina, R.M., Ribeiro, B., Aroso, J., \&Cumming, S.P. (2007). Characteristics of youth players aged 13-15 years classified by skill level. Br J Sports Med 2007; 41: 209-295.

Mamen, A., Resaland, G.K., Mo, D.A., \& Anderson, L.B. (2009). Comparison of Peak Oxygen Uptake in Boys Exercising on Treadmill and Cycle Ergometers. In T Jurimae, N Armstrong, J Jurimae (Eds). Children and Exercice XXIV. Oxfordshire, Routledge, pp: $223-226$.

Metaxas, T., Koutlianos, N., Kouidi, E., \&Deligiannis, A. (2005). Comparative study of field and laboratory tests for the evaluation of aerobic capacity in soccer players. Journal of Strength and Conditioning Association. Vol. 19 (1): 79-84.

Mirwald, R.L., Baxter-Jones, A.D.G., Bailey, D.A., \& Beunen, G.P. (2002). An assessment of maturity from anthropometric measurements. Medicine and Science in Sports and Exercise, 34 (4), 689-694.

Montfort-Steiger, V., Williams, C., \& Armstrong, N. (2005). The reproducibility of an endurance performance test in adolescent cyclists. European Journal of Applied Physiology, 94: 618-625.

Morris, T. (2000). Psychological characteristics and talent identification in soccer. Journal of Sport Sciences, $18,715-726$.

Mueller, W.H., and Martorell, R. (1988). Reliability and accuracy of measurement. In Anthropometric Standardization Reference Manual, edited by T.G. Lohman, A.F. Roche and R. Martorell (Champaign, IL: Human Kinetics), pp. 83-86. 
Nourry, C., Fabre, C., Bart, F., Grosbois, J.M., Berthoin, S., \&Mucci, P. (2004). Evidence of exercise-induced arterial hypoxemia in prepubescent trained children. Pediatric Research. 55: 647 - 681.

Peña Reyes, M.E., Cardenas-Barahona, E., \&Malina, R.M. (1994). Growth, physique, and skeletal maturation of soccer players 7-17 years of age. HumanbiologiaBudapestinensis, 5, 453-458.

Peña Reyes, M.E., \&Malina, R.M. (2004). Growth and Maturity Profile of Youth Swimmers in México. In M Coelho e Silva, R Malina (Eds). Children and Youth in Organized Sports. Coimbra: Imprensa da Universidade.

Philippaerts, R.M., Vaeyens, R., Janssens, M., Van Renterghem, B., Matthys, D., Craen, R., Bourgois, J., Vrijens, J., Beunen, G. \& Malina, R.M. (2006). The relationship between peak height velocity and physical performance in youth soccer players. Journalof Sports Sciences, March 2006; 24(3): 221 - 230.

Ramos, F. (2002). Futebol - Da "Rua" à Competição. Centro de Estudos e Formação Desportiva, Lisboa.

Reilly, T., Bangsbo, J., \& Franks, A. (2000). Anthropometric and physiological predispositions for elite soccer. Journal of sports Sciences. Vol. 18: 669-683.

Reilly, T. (2004). The physiological demands of soccer: implications for youth training. In M Coelho e Silva, RM Malina (Eds). Children and Youth in Organized Sports. Imprensa da Universidade de Coimbra / Coimbra UniversityPress.

Roche, A., Chumlea, W., \&Thissen, D. (1988). Assessing the skeletal maturity of the hand wrist - FELS method. Springfield, Illinois: CC Thomas.

Rowland, T., Goff, D., Martel, L., \&Ferrone, L. (2000). Influence of cardiac functional capacity on gender differences in maximal oxygen uptake in children. Chest. 117: 629-635.

Rowland, T. (2004). Children's Exercise Physiology. $2^{\text {nd }}$ Edition. Champaign Illinois: Human Kinetics.

Seabra, A., Maia, J. A., \& Garganta, R. (2001). Crescimento, maturação, aptidão física, força explosiva e habilidades motoras específicas. Estudo em jovens futebolistas e não futebolistas do sexo masculino dos 12 aos 16 anos de idade. Revista Portuguesa de Ciências do Desporto. 2001, vol. 1, nº 2 [22-35].

Stølen T., Chamari, K., Castagna, C., \&Wisløff, U. (2005). Physiology of soccer: an update. Sports Medicine, 35 (6): $501-536$.

Svensson, M., \&Drust, B. (2005). Testing soccer players. Journal of Sport Sciences. 23(6):601-618

52 - Vaeyens, R., Malina, R., Jansses, M., Van Renterghem, B., Bourgois, J., Vrijens, J., \& Philippaerts, R.M. (2006). A multidisciplinary selection model for youth soccer: the Ghent Youth Soccer Project. Br J Sports Med 2006; 40:928-934.

Vinet, A., Mandigout, W., Nottin, W., N'Guyen, L.D., Lecoq, A.M., Courteix, D., \&Obert, P. (2003). Influence of body composition, haemoglobin concentration, and cardiac size and function of gender differences in maximal oxygen uptake in prepubertal children. Chest. 124: 1494 - 1499.

Welsman, J.R., Bywater, K., Farr, C., Welford, D., \& Armstrong, N. (2005). Reliability of peak VO2 and maximal cardiac output assessed using thoracic bioimpedance in children. European Journal of Applied Physiology, 94: $228-234$.

Wisløff, U., Helgerud, J., \& Hoff, J. (1998). Strength and endurance of elite soccer players. Medicine and Science in Sports and Exercice, 30, $462-467$. 